\title{
Organic copper, iron, manganese and zinc: digestibility, production parameters and egg quality of layers
}

[Cobre, ferro, manganês e zinco orgânico: digestibilidade, parâmetros zootécnicos e qualidade dos ovos de poedeiras]

F.S.G. Crosara ${ }^{1}$, S.K.A. Santos ${ }^{1}$, L.S.S. Silva ${ }^{2}$, G.L. Carvalho ${ }^{2}$, F.H. Litz $^{3}$, E.A. Fernandes ${ }^{4}$

${ }^{1}$ Aluno de pós-graduação - Faculdade de Medicina Veterinária - Universidade Federal de Uberlândia - Uberlândia, MG

${ }^{2}$ Aluno de graduação - Faculdade de Medicina Veterinária - Universidade Federal de Uberlândia - Uberlândia, MG

${ }^{3}$ Faculdade Presidente Antônio Carlos - Uberlândia, MG

${ }^{4}$ Faculdade de Medicina Veterinária - Universidade Federal de Uberlândia - Uberlândia, MG

\begin{abstract}
This study examined the replacement of the inorganic minerals (IM) $\mathrm{Cu}, \mathrm{Fe}, \mathrm{Mn}$ and $\mathrm{Zn}$ with their organic form $(\mathrm{OM})$ in the diet of 67-week-old Dekalb White laying hens by comparing digestibility, production and egg quality. The experiment involved 240 birds, with 48 birds used per treatment and 12 per replicate. Isoenergetic and isonutrient diets were supplemented with $8 \mathrm{mg} \mathrm{Cu}, 50 \mathrm{mg} \mathrm{Fe}, 70 \mathrm{mg} \mathrm{Mn}$ and $50 \mathrm{mg} \mathrm{Zn} \mathrm{per}$ kilogram of diet from an inorganic premix (IM100), from an organic premix (OM100), or the latter at the decreasing inclusion levels of 65\% (OM65), 45\% (OM45) and 35\% (OM35). The following variables were evaluated: production, eggs per housed bird (EHB), viability, egg weight and mass, cracked and lost eggs, digestibility and egg physicochemical traits. Birds fed OM35 and OM45 showed lower production rates, and organic minerals provided the highest egg weights, regardless of their inclusion level. Accordingly, egg mass was similar between IM100, OM45 and OM35, and highest values were obtained with OM100 and OM65. Source or level had no influence on digestibility or egg quality. Supplementation with $2.8 \mathrm{mg}$ $\mathrm{Cu}, 17.5 \mathrm{mg} \mathrm{Fe}, 24.5 \mathrm{~m} \mathrm{~g} \mathrm{Mn}$ and $17.5 \mathrm{mg} \mathrm{Zn}$ per kilogram of diet (OM35) in the last third of the laying cycle provided relevant economic production indices (EHB, viability, egg weight or mass).
\end{abstract}

Keywords: egg composition, production performance, organic minerals, inorganic minerals

\section{RESUMO}

Estudou-se a substituição dos minerais inorgânicos (MI) Cu, Fe, Mn e Zn por minerais orgânicos (MO) na dieta de poedeiras Dekalb White com 67 semanas, comparando-se índices de produção, digestibilidade e qualidade dos ovos. Utilizaram-se 240 aves, 48 aves por tratamento e 12 por repetição. Dietas isoenergéticas e isonutrientes foram suplementadas com $8 \mathrm{mg} \mathrm{Cu}$, 50mg Fe, 70mg Mn e 50mg Zn por kg de ração MI100 e MO100 ou suplementações decrescentes MO65, MO45 e MO35. Avaliou-se produção, ovo por ave alojada (OAA), viabilidade, peso e massa dos ovos, trincados e perdidos, digestibilidade dos nutrientes e características físico-químicas dos ovos. Observaram-se menores índices de produção nas aves dos tratamentos MO35 e MO45 e maiores pesos dos ovos nos tratamentos com minerais orgânicos, independentemente da inclusão. Assim, massas de ovos foram semelhantes para os tratamentos MI100, MO45 e MO35 e maiores para MO100 e MO65. Fontes ou níveis de inclusões não influenciaram a digestibilidade e a qualidade dos ovos. Índices zootécnicos economicamente relevantes (OAA, viabilidade, peso e massa do ovo) foram obtidos com suplementação de 2,8mg Cu, 17,5mg Fe, 24,5mg Mn e 17,5mg Zn por kg de ração (MO35) em poedeiras brancas no último terço do ciclo de postura.

Palavras-chave: composição do ovo, desempenho zootécnico, minerais orgânicos, minerais inorgânicos

Recebido em 22 de setembro de 2020

Aceito em 9 de fevereiro de 2021

E-mail: flaviasgvet@gmail.com 


\section{INTRODUCTION}

Trace minerals, such as $\mathrm{Fe}, \mathrm{Zn}, \mathrm{Mn}$, and $\mathrm{Cu}$, are essential for the metabolic functions that sustain life (Ao and Pierce, 2013). When faced with mineral deficiency, the body reduces its functional activity, as it requires the mineral (Mertz, 1986). Iron is involved in numerous metabolic processes and has a vital function in oxygen transport (Leeson and Summers, 2001). Zinc is a cofactor for over 200 enzymes (Ao and Pierce, 2013), one of which is carbonic anhydrase, which is essential for the supply of carbonate ions to the eggshell (Nys et al., 1999) and also a structural component of DNA as a "zinc finger" (Hossain et al., 2015). Manganese is a cofactor for enzymes involved in the synthesis of mucopolysaccharides and carbonates, essential for eggshell formation and quality (Swiątkiewicz and Koreleski, 2008). Copper participates in the activity of multiple enzymes and red blood cells; bone and elastin formation; myelination of brain cells and the spinal cord; and immune response (Ao and Pierce, 2013).

Diets can have variable levels of $\mathrm{Cu}, \mathrm{Fe}, \mathrm{Mn}$ and $\mathrm{Zn}$ deriving from the ingredients that compose them (Rostagno et al., 2017; Nutrient..., 1994). In grains, the concentrations of these elements depend on the presence of these minerals in the soil and on their transfer to the plant (Nutrient..., 1994). In limestones and phosphates, microminerals are found in higher proportions, which vary according to the source of origin (Rostagno et al., 2017; Teixeira et al., 2005; Nutrient..., 1994). Because the concentration of minerals in a diet is variable and may meet or provide marginal or deficient levels, their supplementation in the diet is essential. Initially used to prevent deficiencies, mineral supplementation has become a requirement to optimize growth or egg production per unit of nutrient intake (Applegate and Angel, 2014).

Micromineral sources for dietary supplementation are divided into organic and inorganic. The chemical form of organic minerals, amino acid chelates, provides greater stability to the mineral in the gastrointestinal tract, resulting in greater solubility, when compared with their inorganic form (Vieira, 2008). Thus, organic sources have higher bioavailability and can be supplemented in the diet at lower levels, providing a reduction in excreted amounts (Yenice et al., 2015) and supporting bird performance (Ao and Pierce, 2013). The recommendations of Rostagno et al. (2017) correspond to inorganic mineral supplementation at around $43 \%$.

Characteristics of minerals, such as chemical form (free or combined) and bonds between atoms (covalent or ionic), interfere with their solubility. Interactions between minerals (Fe- $\mathrm{Zn}, \mathrm{Fe}-\mathrm{Ca}, \mathrm{Ca}-$ $\mathrm{Zn}, \mathrm{Zn}-\mathrm{Cu}, \mathrm{Ca}-\mathrm{Mg}$ ), competition for transport sites (such as the divalent metal transporter protein DMT-1) and the presence of inhibitors (phytates, tannins and oxalates) or facilitators (organic acids and amino acids) of absorption in the diet are factors that influence bioavailability (Cozzolino, 1997). Physicochemical conditions, $\mathrm{pH}$ and intestinal viscosity compromise mineral absorption (Regina and Beterchini, 2010). Therefore, the present study, involving supplementation with copper, iron, manganese and zinc sulfates and methionine chelates at commercial and decreasing levels in organic form, was developed to establish lower levels of inclusion of organic minerals in view of their better solubility, stability and bioavailability. To this end, the production performance and egg quality of Dekalb White laying hens in the last third of the production cycle were evaluated.

\section{MATERIAL AND METHODS}

The study was conducted on the Glória Experimental Farm, at the Federal University of Uberlândia (UFU), between May and August 2018. All experimental procedures followed the ethical standards of and were approved by the Animal Use Ethics Committee (approval no. 004/18 CEUA/UFU). Dekalb White layers at 67 weeks of age were randomly distributed into cages equipped with nipple drinkers and linear feed troughs, at the rate of 12 birds per cage, under a housing density of $416 \mathrm{~cm}^{2}$ bird $^{-1}$. Birds received $15 \mathrm{~h}$ of light and $108 \mathrm{~g}$ of feed daily, and water was available ad libitum. The experiment was laid out in a completely randomized design with five treatments and four replicates with 48 birds per treatment, totaling 240 layers.

The studied minerals were copper $(\mathrm{Cu})$, iron $(\mathrm{Fe})$, manganese $(\mathrm{Mn})$ and zinc $(\mathrm{Zn})$. Two premixes were used, both containing the same concentration of the tested elements. In the inorganic premix (IM), the minerals were used in the form of salts, namely, copper sulfate, iron 
sulfate, manganese sulfate and zinc sulfate. In the organic premix $(\mathrm{OM})$, the metal ions were chelated to methionine at the chelation percentages of $94.4 \%(\mathrm{Cu}), 90.1 \%(\mathrm{Fe}) 91.5 \%$ $(\mathrm{Mn})$ and $91.9 \%(\mathrm{Zn})$. The five treatments consisted of the premix used (inorganic and organic minerals) and inclusion levels. The basal diet was supplemented with an inorganic (IM100) or an organic (OM100) mineral premix with the same mineral concentrations used commercially or decreasing levels of the organic mineral premix (OM65 [65\% of OM100], OM45 [45\% of OM100] and OM35 [35\% of OM100]). All diets were isoenergetic, isonutrient, free of phytase and maize, and soybean meal-based (Table 1).

Table 1. Ingredients and calculated nutrients of the experimental diets

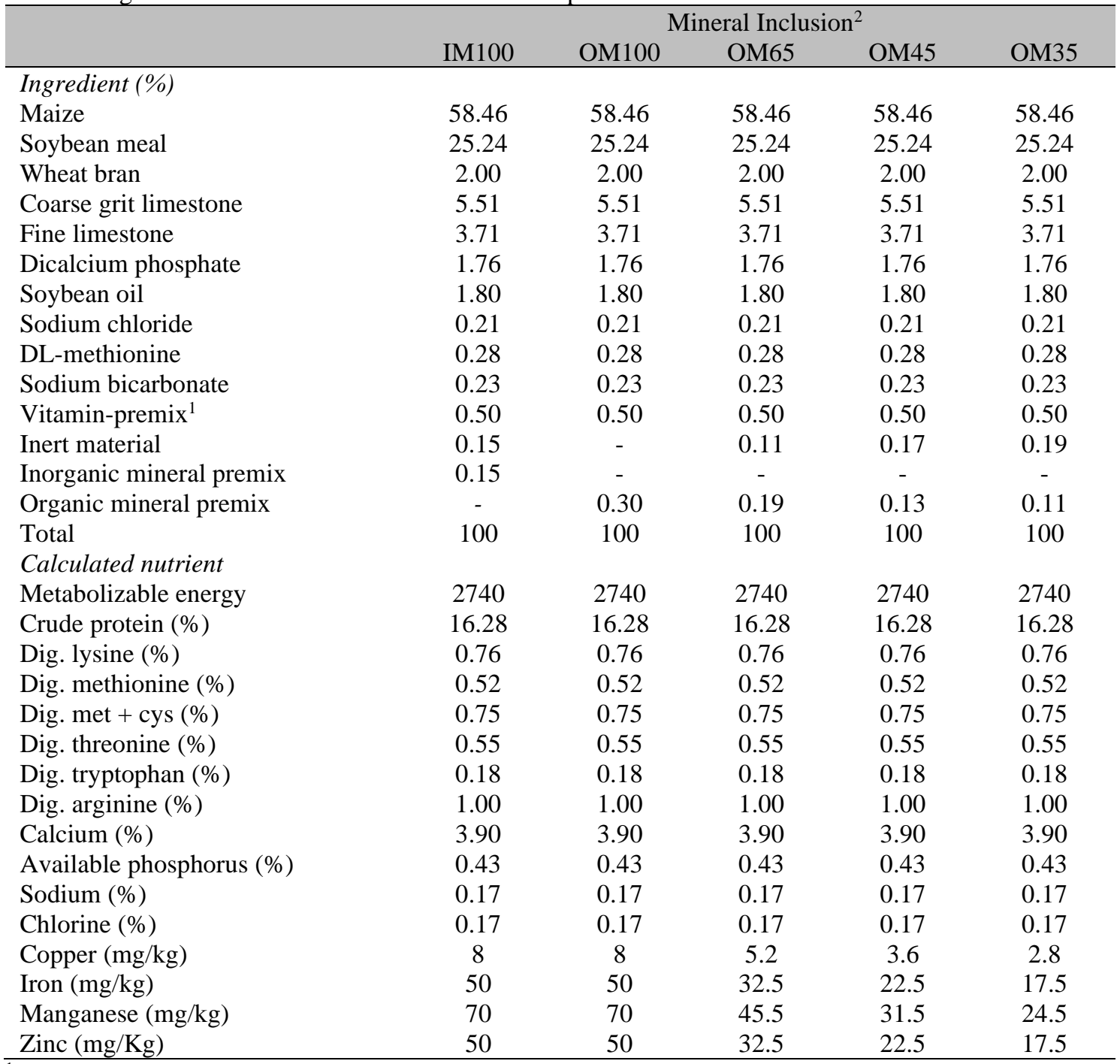

${ }^{1}$ Vitamin composition and additives per kilogram of diet: folic acid (min) $0.125 \mathrm{mcg}$; pantothenic acid (min) $1.61 \mathrm{mg}$; biotin (min) 0.00375mg; choline ( $\mathrm{min}) 0.0522 \mathrm{~g}$; niacin (min) 5mg; vit A (min) 2000 IU; vit B1 (min) $0.05 \mathrm{mg}$; vit. B12 (min) $2.5 \mathrm{mcg}$; vit. B2 (min) 0.750mg; vit. B6 (min) 4,25mg; vit D3 (min) 575 IU; vit E (min) 3.75 IU; vit K3 (min) $0.25 \mathrm{mg}$; Se ( $\mathrm{min}) 0.0625 \mathrm{mg}$; iodine $1.2 \mathrm{mg}$; halquinol $7.5 \mathrm{mg} .{ }^{2} \mathrm{IM} 100=$ inorganic mineral; OM100 = organic mineral at concentrations used commercially; OM65 = average $65 \%$ of OM100; OM45 = average $45 \%$ of OM100; OM35= average $35 \%$ of OM100. 
The experiment lasted 98 days, of which the first 70 were used for the nutritional adaptation of the birds to the diet and acclimation to the experimental management. Production percentage, number of eggs per housed bird (EHB), egg weight and mass, bird viability and percentage of cracked and lost eggs were recorded between 77 and 80 weeks of age. The material for egg physical-chemical analysis and digestibility was harvested at the end of said period. Nutrient digestibility was measured by the total excreta collection method, for five consecutive days, in a methodology similar to that proposed by Sibbald and Slinger (1961) to calculate metabolizable energy. During excreta collection, feathers and other foreign bodies were removed. The excreta were packed in identified plastic bags, weighed and frozen. After thawing at room temperature, they were homogenized, dried in a forced-air oven at $55^{\circ} \mathrm{C}$ for $72 \mathrm{~h}$ and ground.
Dry matter $\left(\mathrm{DM}, 105^{\circ} \mathrm{C}\right)$, ether extract (EE), crude protein $(\mathrm{CP})$ and mineral matter $(\mathrm{MM})$ contents in the excreta were determined following the methodology of the Brazilian Compendium of Animal Nutrition (Compêndio..., 2009) and gross energy was measured using an IKA-WERKE C2000 Basic bomb calorimeter. Samples with 0.5 $\mathrm{g}$ of DM were digested in $5 \mathrm{~mL}$ of nitric-perchloric acid solution and heated to $210^{\circ} \mathrm{C}$ until a maximum reduction of $1 \mathrm{~mL}$, when they were diluted in warm distilled water, stirred, filtered and placed in a volumetric flask to complete $50 \mathrm{~mL}$. Calcium was analyzed using an atomic absorption spectrophotometer and phosphorus by colorimetry. The same analyses were carried out on the diets for later calculations of digestibility, considering the feed consumed and excreta free of water, i.e., DM after drying at $105^{\circ} \mathrm{C}$.

$$
\text { Apparent digestibility }=\frac{\text { Nutrient intake }- \text { Nutrient excretion }}{\text { Nutrient intake }} \times 100
$$

For the analysis of egg quality, 14 eggs from each treatment (each unit was considered a replicate) were evaluated using the Digital Egg Tester DET6000 instrument for eggshell thickness $(\mu \mathrm{m})$ and resistance (Kgf), haugh unit (HU), yolk color and the North American quality grading that classifies eggs as AA, A or B, as follows: AA eggs eggshell clean, unbroken and normal, air cell up to $3.17 \mathrm{~mm}$ in height, albumen clear and firm, yolk with outline slightly defined and free from defects; A eggs - eggshell clean, unbroken and normal, air cell up to $4.76 \mathrm{~mm}$ in height, albumen clear and reasonably firm, yolk with outline fairly well defined and free from defects; B eggs eggshell stained, unbroken, with abnormalities, air cell higher than $4.76 \mathrm{~mm}$, albumen weak and watery with small blood and meat spots possibly present, yolk flattened, with outline plainly visible (Stadelman, 1994).

Eighteen other eggs were weighed individually on a $0.001-g$ precision scale and evaluated for specific gravity using the saline immersion method (Hamilton, 1982). Then, the eggs were broken, and the absolutes weights of yolk (YW) and eggshell $(\mathrm{EW})$ were obtained on a precision scale. Shells were previously washed under running water to remove the adhered albumen and dried at room temperature. Albumen weight (AW) was calculated by difference $(\mathrm{AW}=\mathrm{EW}-\mathrm{YW}$ -
SW). The respective percentages were determined relative to the weight of the whole egg.

For the chemical analyses, six pools of three yolks and six pools of three albumens were made, generating six replicates per treatment. Each replicate of yolk and albumen was placed on an aluminum tray and homogenized. Next, the $\mathrm{pH}$ was determined using a Gehaka ${ }^{\circledR}$ digital potentiometer. The trays were placed in a forcedair oven at $55^{\circ} \mathrm{C}$ for $72 \mathrm{~h}$, cooled to room temperature and weighed to determine the DM content. Dry matter $\left(105^{\circ} \mathrm{C}\right), \mathrm{mm}$ and $\mathrm{CP}$ were determined by the Kejdhal method and EE was measured using the Shoxlet extractor. The latter component was only determined in the yolks, following the same methodology used for excreta and diets. These variables were expressed on an as-is basis. Eggshells were ground with the membrane and 0.1-g samples were digested in nitric-perchloric acid in a digester block where the temperature was gradually increased to $210^{\circ} \mathrm{C}$ until the mixture was reduced to a maximum of $1 \mathrm{~mL}$ and then diluted with distilled water to complete $50 \mathrm{~mL}$. Calcium and magnesium were analyzed by atomic absorption spectrophotometry and phosphorus by colorimetry. 
The production parameters of the bird subjected to the treatments with organic minerals (OM35, OM45, OM65 and OM100) were evaluated based on the animal's response to the increasing addition of $\mathrm{Cu}, \mathrm{Fe}, \mathrm{Mn}$ and $\mathrm{Zn}$, by the dose-response method. The phenomenon resulting from the addition of a nutrient to the diet has four distinct phases: initial - the levels ensure maintenance; response - animals show growth and efficiency until they stabilize; stable - in this phase, the nutrient levels do not influence production or cause toxicity; toxic - production declines (Euclydes and Rostagno, 2001). The optimum level is obtained by the intersection point between the ascending line and the plateau (Sakomura and Rostagno, 2007). Data were analyzed for normality of residues and homogeneity of variances and then subjected to ANOVA. Means were compared by Scott-Knott's test $(\mathrm{P}<0.05)$. Data analysis was carried out using Sisvar 5.6 software (Ferreira, 2000).

\section{RESULTS}

Table 2 describes the production parameters and the apparent digestibility of diets and nutrients. Birds that received the OM35 and OM45 treatments showed lower production percentages. However, eggs per housed bird (EHB) and bird viability responded similarly, regardless of mineral origin or premix inclusion level. Birds that received diets with organic minerals, regardless of mineral premix inclusion level, laid eggs with higher weights than those which received the IM100 treatment. For egg mass, a production index that involves egg weight and production percentage, there was no difference between the IM100, OM35 and OM45 treatments, whereas the layers fed OM65 and OM100 produced eggs with the highest masses. Despite the unpredictability of eggs cracking or being lost, the percentage of these occurrences $(\mathrm{CV}=340.98)$ did not vary with the mineral sources or supplementation levels.

Table 2. Production parameters and apparent digestibility of diets and nutrients as a function of the levels of inclusion and source of the microminerals $\mathrm{Fe}, \mathrm{Cu}, \mathrm{Mn}, \mathrm{Zn}$ in the diet of DeKalb. White layers in the last third of the laying cycle.

\begin{tabular}{|c|c|c|c|c|c|c|c|c|}
\hline \multicolumn{9}{|c|}{ Mineral inclusio } \\
\hline & IM100 & OM100 & OM65 & OM45 & OM35 & Mean & $C V$ & $p$ \\
\hline \multicolumn{9}{|c|}{ Production index } \\
\hline Production $(\%)$ & $87.40^{\mathrm{a}}$ & $88.92^{\mathrm{a}}$ & $87.79^{a}$ & $84.37^{\mathrm{b}}$ & $83.37^{\mathrm{b}}$ & 86.37 & 11.24 & 0.0000 \\
\hline $\mathrm{EHB}^{1}$ & 23.88 & 24.90 & 24.58 & 23.62 & 22.91 & 23.98 & 5.44 & 0.2643 \\
\hline Viability (\%) & 93.75 & 100.00 & 100.00 & 100.00 & 92.36 & 97.22 & 6.06 & 0.2036 \\
\hline Egg weight (g) & $64.53^{c}$ & $65.90^{\mathrm{a}}$ & $65.84^{\mathrm{a}}$ & $65.15^{\mathrm{b}}$ & $65.47^{\mathrm{a}}$ & 65.38 & 2.71 & 0.0000 \\
\hline Egg mass (g/day) & $56.40^{\mathrm{b}}$ & $58.57^{\mathrm{a}}$ & $57.80^{\mathrm{a}}$ & $55.01^{\mathrm{b}}$ & $54.57^{\mathrm{b}}$ & 56.47 & 11.49 & 0.0000 \\
\hline Cracked + Lost (\%) & 1.06 & 0.50 & 0.47 & 1.16 & 1.26 & 0.89 & 340.98 & 0.1423 \\
\hline \multicolumn{9}{|c|}{ Apparent nutrient digestibility } \\
\hline Feed $(\%)$ & 75.15 & 76.24 & 75.16 & 77.16 & 73.43 & 75.43 & 2.55 & 0.1305 \\
\hline Energy (\%) & 80.14 & 80.40 & 79.37 & 81.43 & 78.96 & 80.06 & 1.99 & 0.2652 \\
\hline Crude protein $(\%)$ & 47.75 & 52.42 & 50.6 & 54.43 & 44.84 & 50.01 & 12.45 & 0.2567 \\
\hline Fat $(\%)$ & 85.75 & 84.09 & 86.16 & 87.00 & 81.68 & 84.94 & 4.96 & 0.4397 \\
\hline Mineral matter $(\%)$ & 43.06 & 49.77 & 46.61 & 52.48 & 44.16 & 47.22 & 16.4 & 0.4285 \\
\hline Calcium (\%) & 55.95 & 61.73 & 57.53 & 61.28 & 52.41 & 57.78 & 12.94 & 0.4032 \\
\hline Phosphorus (\%) & 25.79 & 27.57 & 25.51 & 28.57 & 19.03 & 25.29 & 35.22 & 0.6054 \\
\hline
\end{tabular}

${ }^{1}$ EHB: eggs per housed bird; ${ }^{2}$ IM100 = inorganic mineral; OM100 = organic mineral at concentrations used commercially; OM65 = average 65\% of OM100; OM45 = average 45\% of OM100; OM35 = average 35\% of OM100. Means followed by different letters in the row differ by Scott-Knott's test at 0.05 significance.

Neither the origin of the minerals (sulfates or methionine chelates) nor the inclusion levels of $\mathrm{Fe}, \mathrm{Mn}, \mathrm{Zn}$ and $\mathrm{Cu}$ influenced the apparent digestibility of the diet or its $\mathrm{CP}$, fat (EE), mm, calcium and phosphorus nutrients. On average, the apparent digestibility coefficients were as follows: diet $-75.43 \%$, energy $-80.06 \%$, CP $50.01 \%$, fat $-84.94 \%$, mm $-47.22 \%$, calcium -
$57.78 \%$ and phosphorus - $25.29 \%$. The use of organic minerals had significant effects on egg weight, regardless of their inclusion level. When the egg components were evaluated separately (Table 3), there were no differences in the relative weights of eggshell, yolk or albumen between the mineral sources and levels of inclusion in the diet. 
Table 3. Egg physical-chemical and quality traits according to the levels of inclusion and origin of the microminerals $\mathrm{Fe}, \mathrm{Cu}, \mathrm{Mn}, \mathrm{Zn}$, in the diet of DeKalb White layers in the last third of the laying cycle

\begin{tabular}{|c|c|c|c|c|c|c|c|c|}
\hline & & $\mathrm{N}$ & ineral in & lusion $^{2}$ & & & & \\
\hline & IM100 & OM100 & OM65 & OM45 & OM35 & Mean & $C V$ & $p$ \\
\hline Grading $(\% \text { AA })^{1}$ & 100.00 & 92.85 & 85.71 & 71.42 & 64.28 & 82.85 & 44.19 & 0.0700 \\
\hline & & & gshell & & & & & \\
\hline Eggshell (\%) & 10.25 & 10.35 & 10.12 & 10.02 & 10.23 & 10.19 & 6.16 & 0.5580 \\
\hline Surface $\left(\mathrm{cm}^{2}\right)$ & 76.16 & 75.51 & 75.68 & 74.89 & 75.76 & 75.60 & 4.69 & 0.8733 \\
\hline Eggshell index $\left(\mathrm{g} / \mathrm{cm}^{2}\right)$ & 8.84 & 8.89 & 8.70 & 8.57 & 8.80 & 8.76 & 6.35 & 0.4552 \\
\hline Specific gravity & 1083 & 1081 & 1080 & 1082 & 1083 & 1082 & 0.15 & 0.1555 \\
\hline Eggshell thickness $(\mu \mathrm{m})$ & 412 & 419 & 420 & 421 & 410 & 416 & 4.79 & 0.4856 \\
\hline Eggshell resistance (Kgf) & 4.19 & 4.37 & 4.29 & 4.40 & 3.87 & 4.22 & 4.22 & 0.6618 \\
\hline Mineral matter $(\%)$ & 95.14 & 95.08 & 95.28 & 95.21 & 95.31 & 95.21 & 0.25 & 0.4164 \\
\hline Calcium (\%) & 40.00 & 40.44 & 39.62 & 40.17 & 40.20 & 40.08 & 3.54 & 0.8931 \\
\hline Phosphorus (\%) & 0.13 & 0.13 & 0.14 & 0.13 & 0.13 & 0.13 & 6.68 & 0.1596 \\
\hline Magnesium (\%) & 0.41 & 0.45 & 0.43 & 0.43 & 0.43 & 0.43 & 9.01 & 0.4697 \\
\hline & & & olk & & & & & \\
\hline Yolk (\%) & 26.56 & 26.86 & 26.69 & 26.87 & 26.24 & 26.64 & 9.10 & 0.9338 \\
\hline $\mathrm{pH}$ & 5.96 & 5.98 & 5.95 & 5.95 & 5.95 & 5.95 & 1.21 & 0.9532 \\
\hline Water $(\%)$ & 50.37 & 50.43 & 50.52 & 50.76 & 50.84 & 50.58 & 1.48 & 0.7581 \\
\hline Yolk color & 5.79 & 5.79 & 5.86 & 6.21 & 5.93 & 5.91 & 7.18 & 0.0542 \\
\hline Ether extract $(\%)$ & 25.72 & 25.48 & 25.51 & 25.70 & 26.13 & 25.71 & 3.49 & 0.7366 \\
\hline Crude protein $(\%)$ & 17.03 & 16.65 & 16.69 & 16.85 & 16.42 & 16.73 & 2.28 & 0.1017 \\
\hline Mineral matter $(\%)$ & 1.79 & 1.86 & 1.80 & 1.78 & 1.76 & 1.79 & 7.19 & 0.7151 \\
\hline & & & umen & & & & & \\
\hline Albumen $(\%)$ & 63.18 & 62.78 & 63.19 & 63.10 & 63.53 & 63.15 & 4.09 & 0.9416 \\
\hline $\mathrm{pH}$ & 8.65 & 8.62 & 8.73 & 8.72 & 8.46 & 8.63 & 1.94 & 0.0690 \\
\hline Haugh unit & 79.12 & 77.43 & 78.23 & 76.27 & 74.74 & 77.16 & 8.32 & 0.4167 \\
\hline Water $(\%)$ & 89.74 & 89.57 & 89.78 & 89.71 & 89.53 & 89.66 & 0.49 & 0.8046 \\
\hline Crude protein $(\%)$ & 9.34 & 9.55 & 9.37 & 9.41 & 9.56 & 9.44 & 4.46 & 0.8168 \\
\hline Mineral matter (\%) & 0.79 & 0.75 & 0.77 & 0.73 & 0.80 & 0.77 & 8.07 & 0.4504 \\
\hline
\end{tabular}

Means followed by different letters in the row differ by Scott-Knott's test at 0.05 significance.

${ }^{1}$ AA eggs - eggshell clean, unbroken and normal, air cell up to $3.17 \mathrm{~mm}$ in height, albumen clear and firm, yolk with outline slightly defined and free from defects

${ }^{2}$ IM100 = inorganic mineral; OM100 = organic mineral at concentrations used commercially; OM65 = average $65 \%$ of OM100; OM45 = average $45 \%$ of OM100; OM35 = average $35 \%$ of OM100.

Overall egg quality, calculated by the percentage of AA eggs, and the quality of the internal content (yolk and albumen, measured by $\mathrm{pH}$, yolk color and hU) and eggshell (represented by eggshell index, specific gravity, thickness and resistance) were equal between the treatment groups. Therefore, the mineral origin (sulfates or methionine chelates) and decreasing inclusion levels (OM65, OM45 and OM35) did not influence any of these quality measurements. The chemical composition of the yolk and albumen (water, $\mathrm{CP}, \mathrm{EE}$ and $\mathrm{mm}$ ), the $\mathrm{mm}$ of the eggshell and the percentage of the main minerals (calcium, magnesium and phosphorus) were similar between treatments with different mineral sources, inorganic and organic. In other words, egg composition and quality did not depend on the mineral source or its level of inclusion in the diet.

\section{DISCUSSION}

Supplementation with organic minerals with high bioavailability and at levels lower than frequent supplementation with inorganic minerals can maintain or increase performance in laying hens (Ao et al., 2009). Current experiments aim at reducing inclusion levels in the diet while still sustaining the metabolism and productivity of birds, thus helping to reduce the environmental impact of minerals eliminated in the feces of bird flocks. 
The supplementation levels suggested by Rostagno et al. (2017) for inorganic minerals are $9.4 \mathrm{mg} / \mathrm{kg} \mathrm{Cu}, 45.85 \mathrm{mg} / \mathrm{kg} \mathrm{Fe}, 64.20 \mathrm{mg} / \mathrm{kg} \mathrm{Mn}$ and $59.63 \mathrm{mg} / \mathrm{kg} \mathrm{Zn}$, whereas the recommended levels for organic minerals are $3.98 \mathrm{mg} / \mathrm{kg} \mathrm{Cu}$, $19.88 \mathrm{mg} / \mathrm{kg} \mathrm{Fe}, 28.49 \mathrm{mg} / \mathrm{kg} \mathrm{Mn}$ and $26.50 \mathrm{mg} / \mathrm{kg}$ $\mathrm{Zn}$. These recommendations for organic minerals represent a decrease of about $43 \%$ in relation to their inorganic form. Another reference, the NRC (Nutrient..., 1994), recommends $45 \mathrm{mg} / \mathrm{kg} \mathrm{Fe}$, $20 \mathrm{mg} / \mathrm{kg} \mathrm{Mn}$ and $35 \mathrm{mg} / \mathrm{kg} \mathrm{Zn}$, but has no recommendations for $\mathrm{Cu}$. It is noteworthy that these recommendations were made with a 20 -year interval. In the present experiment, the inclusion levels for inorganic (IM100) and organic (OM100) minerals were $8 \mathrm{mg} / \mathrm{kg} \mathrm{Cu}, 50 \mathrm{mg} / \mathrm{kg} \mathrm{Fe}$, $70 \mathrm{mg} / \mathrm{kg} \mathrm{Mn}$ and $50 \mathrm{mg} / \mathrm{kg} \mathrm{Zn}$, which are very similar to those recommended by Rostagno et al. (2017) for inorganic minerals. The OM45 and OM35 treatments, in turn, contained lower values than those proposed by Rostagno et al. (2017).

Minerals are supplemented in the diet to meet the metabolic and productive requirements of laying hens. The OM35 treatment, whose supplementation is equivalent to $35 \%$ of the OM100 treatment $(2.8 \mathrm{mg} / \mathrm{kg} \mathrm{Cu}, 17.7 \mathrm{mg} / \mathrm{kg} \mathrm{Fe}$, $24.5 \mathrm{mg} / \mathrm{kg} \mathrm{Mn}$ and $17.5 \mathrm{mg} / \mathrm{kg} \mathrm{Zn}$ ), showed to meet these requirements based on the EHB and egg mass indexes, without compromising the egg quality parameters or the digestibility of the diet and its nutrients. In other studies, researchers tested a reduction in dietary inclusion levels of organic minerals and observed no losses to bird performance or egg quality. Carvalho et al. (2016) evaluated decreasing inclusion levels of an organic mineral premix (90, 80 and $70 \%)$ and achieved an optimal result using $6.3 \mathrm{mg} / \mathrm{kg} \mathrm{Cu}$, $21 \mathrm{mg} / \mathrm{kg} \mathrm{Fe}, 42 \mathrm{mg} / \mathrm{kg} \mathrm{Mn}$ and $42 \mathrm{mg} / \mathrm{kg} \mathrm{Zn}$, corresponding to the $70 \%$ inclusion level.

Figueiredo Júnior et al. (2013) tested decreasing levels of organic minerals (66 and 33\%) and observed an improvement in production with the supplementation of $6.6 \mathrm{mg} / \mathrm{kg} \mathrm{Cu}, 26.4 \mathrm{mg} / \mathrm{kg} \mathrm{Fe}$, $52.8 \mathrm{mg} / \mathrm{kg} \mathrm{Mn}$ and $36 \mathrm{mg} / \mathrm{kg} \mathrm{Zn}$. However, in their study, birds fed diets with the inclusion of $3.3 \mathrm{mg} / \mathrm{kg} \mathrm{Cu}, 13.2 \mathrm{mg} / \mathrm{kg} \mathrm{Fe}, 26.4 \mathrm{mg} / \mathrm{kg} \mathrm{Mn}$ and $18 \mathrm{mg} / \mathrm{kg} \mathrm{Zn} \mathrm{(similar} \mathrm{concentrations} \mathrm{to} \mathrm{those}$ present in the OM35 treatment) exhibited similar parameters to those shown by the birds fed the inorganic premix. Gheisari et al. (2011) recommended organic mineral supplementation with $3.5 \mathrm{mg} / \mathrm{kg} \mathrm{Cu}, 20 \mathrm{mg} / \mathrm{kg} \mathrm{Mn}$ and $20 \mathrm{mg} / \mathrm{kg} \mathrm{Zn}$, describing no losses to performance, but improved eggshell and albumen quality, as compared with inorganic sources (sulfates and oxides). Yenice et al. (2015) supplemented organic $\mathrm{Mn}, \mathrm{Zn}, \mathrm{Cu}$ and $\mathrm{Cr}$ and found an increase in the bioavailability of the microminerals as compared with their inorganic sources, confirming these results.

The birds' response to the increasing addition of $\mathrm{Cu}, \mathrm{Fe}, \mathrm{Mn}$ and $\mathrm{Zn}$, in treatments OM35, OM45, OM65 and OM100 did not fit the dose-response model, in which the optimal supplementation level is determined by the intersection point between the ascending line and the plateau (Sakomura and Rostagno, 2007). The data were similar, and this linearity indicates that the inclusions were made in the stable phase, that is, in the plateau. Variations in mineral inclusion rates to meet nutritional requirements can be justified by the following factors: bioavailability of the supplementation source (Rostagno et al., 2017); use of ingredients carrying other minerals in their composition (Rostagno et al., 2017; Nutrient..., 1994; Avelar et al., 2009); excess of $\mathrm{P}$, which can form insoluble salts with $\mathrm{Fe}, \mathrm{mg}, \mathrm{Al}$ and Ca (Maiorka and Macari, 2002); and the presence of phytate, which, once complexed with bivalent cations such as $\mathrm{Ca}, \mathrm{Mn}, \mathrm{mg}, \mathrm{Fe}, \mathrm{Zn}$, makes them unavailable to the animal (Newman, 1991).

In this experiment, the apparent digestibility coefficients of $\mathrm{Ca}(57.78 \%)$ and $\mathrm{P}(25.29 \%)$, which were supplemented in the diet using limestone and dicalcium phosphate, are in line with the values described by Sordi (2019) for laying hens. The mineral sources and inclusion levels did not influence their digestibility. This result is in contrast to the reports of Yenice et al. (2015), who described an increase in the bioavailability of dietary $\mathrm{Ca}$ and $\mathrm{P}$ following organic mineral supplementation. The increasing egg weight in response to the use of organic minerals, irrespective of the inclusion level, could be attributed to the fraction of methionine chelated to the minerals. Lesson and Summers (2005) mentioned methionine among the possible nutrients that can be adjusted to manipulate egg weight. An increase in egg weight was also observed by Figueiredo Júnior et al. (2013) at the lowest levels of inclusion of organic minerals in relation to the inclusion of inorganic minerals; and 
by Nunes et al. (2013), who attributed it to the increase in albumen content.

The egg physicochemical traits were not influenced by the mineral source or their level of inclusion in the diet. The quality grading, as measured by the percentage of AA eggs, revealed a trend $(p=0.0700)$. Nonetheless, the birds of all treatments produced eggs classified as special according to the quality categories defined by the American wholesale market (Stadelman, 1994). The yolk color $(\mathrm{p}=0.0542)$ obtained in the treatments would not indicate significant variations in this parameter, which ranges from light yellow (1) to dark orange/reddish (16) (Domingues and Faria, 2019). The albumen pH (p $=0.0690)$ demonstrates the fluidization of this fraction and is directly related to the haugh unit, which measures the freshness of eggs (Oliveira and Oliveira, 2013) and which, in turn, did not vary with mineral origin or inclusion level.

\section{CONCLUSION}

Dietary supplementation with the organic minerals copper, iron, manganese and zinc at the tested inclusions levels, compared with the diet supplemented with inorganic minerals at commercial inclusion levels, provided similar performance in terms of production indices (EHB, viability and cracked and lost eggs), egg physicochemical traits, as well as feed and nutrient digestibility. Therefore, supplementation with organic minerals at the concentrations of $2.8 \mathrm{mg} \mathrm{Cu}, 17.7 \mathrm{mg} \mathrm{Fe}, 24.5 \mathrm{mg} \mathrm{Mn}$ and $17.5 \mathrm{mg} \mathrm{Zn}$ (OM35) meets the dietary requirements of laying hens in the last third of the production cycle.

\section{REFERENCES}

AO, T.; PIERCE, J.L. The replacement of inorganic mineral salts with mineral proteinates in poultry diets. Worlds Poult. Sci. J., v.69, p.5-16, 2013.

AO, T.; PIERCE, J.L.; PESCATORE, A.J. et al. Effects of feeding reduced levels of organic minerals (Bioplex ${ }^{\circledR}$ ) on the development of white layer pullets. Poult. Sci., v.88, p.197-209, 2009.

APPLEGATE, T.J.; ANGEL, R. Nutrient requirements of poultry publication:history and need for an update. J. Appl. Poult. Res., v.23, p.567-575, 2014.
AVELAR, A.C.; FERREIRA, W.M.; BRITO, W.; MENEZES, M.A.B.C. Composição mineral de fosfatos, calcário e farinha de ossos usados na agropecuária brasileira. Arq. Zootec., v.58, p.737740, 2009.

CARVALHO, L.S.S.; VILELA, D.R.; FAGUNDES, N.S. et al. Qualidade de ovos e desempenho produtivo de poedeiras em segundo ciclo de postura alimentadas com microminerais quelatados a aminoácidos. Ciênc. Anim. Bras., v.17, p.491-500, 2016.

COMPÊNDIO brasileiro de alimentação animal. Guia de métodos analíticos. 2.ed. São Paulo: Sindicato Nacional da Indústria de Alimentação Animal, 2009. 383p.

COZZOLINO, S.M.F. Biodisponibilidade de minerais. Rev. Nutr., v.10, p.87-98, 1997.

DOMINGUES, C.H.F.; FARIA, D.E. Qualidade interna e externa do ovo. In: FARIA, D.E.; FARIA FILHO, D.E.; MAZALLI, M.R.; MACARI, M. (Eds.). Produção e processamento de ovos de poedeiras comerciais. Campinas: FACTA/FAPESP, 2019. p.245-268.

EUCLYDES, R.F.; ROSTAGNO, H.S. Estimativas dos níveis nutricionais via experimentos de desempenho. In: WORKSHOP LATINO AMERICANO AJINOMOTO BIOLATINA, 2001, Foz do Iguaçu. Anais... Foz do Iguaçu: [s,n], 2001. p.77-88.

FERREIRA, D.F. Sistema de análise estatística para dados balanceados - SISVAR. Lavras: UFLA/DEX, 2000. (Software).

FIGUEIREDO JÚNIOR, J.P.; COSTA, F.G.P.; GIVISIEZ, P.E.N. et al. Substituição de minerais inorgânicos por orgânicos na alimentação de poedeiras semipesadas. Arq. Bras. Med. Vet. Zootec., v.65, p.513-518, 2013.

GHEISARI, A.A.; SANEI, S.; SAMIE, A. Effect of diets supplemented with different levels of manganese, zinc, and copper from their organic or inorganic sources on egg production and quality characteristics in layinghens. Biol. Trace Elem. Res., v.142, p.557-571, 2011.

HAMILTON, R.G.M. Methods and factors that affect the measurement of egg shell quality. Poult. Sci., v.61, p.2022-2039, 1982. 
HOSSAIN, M.A.; BARROW, J.J.; SHEN, Y. et al Artificial zinc finger DNA binding domains: versatile tools for genome engineering and modulation of gene expression. J. Cell. Biochem., v.116, p.2435-2444, 2015.

LESSON, S.; SUMMERS, J. Nutrition of the chicken. Ghelph: University books, 2001. 591p.

MAIORKA, A.; MACARI, M. Absorção de minerais. In: MACARI, M.; FURLAN, R.L.; GONZALES, E. (Eds.) Fisiologia aviária aplicada a frangos de corte. Campinas: FACTA, 2002. 375p.

MERTZ, W. Trace elements inhuman and animal nutrition. 5.ed. Nova York: Academic Press, 1986. 499p.

NEWMAN K. Phytase: the enzyme, its origin e characteristics: impact e potential for increasing phosphorus availability. In: BIOTECHNOLOGY IN THE FEED INDUSTRY, 7., 1991; Nicholasville. Proceedings... Nicholasville: Alltech Technical Publications, 1991. p.169-177.

NUNES, J.K.; SANTOS, V.L.; ROSSI, P. et al. Qualidade de ovos e resistência óssea de poedeiras alimentadas com minerais orgânicos. Arq. Bras. Med. Vet. Zootec., v.65, p.610-618, 2013.

NUTRIENT requirements of poultry. 9.ed. Washington: National Academies Press, 1994.

NYS, Y.; HINCKE, M.; ARIAS, J.L. et al. Avian eggshell mineralization. Poult. Avian Biol. Rev., v.10, p.143-166, 1999.

OLIVEIRA, B.L.; OLIVEIRA, D.D. Qualidade e tecnologia de ovos. Lavras: UFLA, 2013. 224p.

REGINA, R.; BETERCHINI, A.G. Minerais. In: REGINA, R. (Ed.) Nutrição animal, principais ingredientes e manejo. São Paulo: Fundação Cargill, 2010. p.173-205.
ROSTAGNO, H.S.; ALBINO, L.F.T.; HANNAS, M.I. et al. Tabelas brasileiras para aves e suínos: composição de alimentos e exigências nutricionais. 4.ed. Viçosa: Universidade Federal de Viçosa, 2017. 488p

SAKOMURA, N.K.; ROSTAGNO, H.S. Métodos de pesquisa em nutrição de monogástricos. Jaboticabal: FUNEP, 2007. 283p.

SIBBALD, I.R.; SLINGER, S.J. Measuring avaiable energy in poultry feeds. Feedstuffs, v.33, p.18-24, 1961.

SORDI, C. Digestibilidade de cálcio e de fósforo de fontes inorgânicas para galinhas Poedeiras. 2019. 72f. Dissertação (Mestrado em Zootecnia) - Centro de Educação Superior do Oeste, Universidade do Estado de Santa Catarina, Chapecó, SC.

STADELMAN, W.J. Quality identification of shell eggs. In: STADELMAN, W.J.; COTTERILL, O.J. (Eds.). Egg science and technology. 4.ed. New York: Food Products Press, 1994. p.39-66.

SWIATKIEWICZ，S.; KORELESKI， J. The effect of zinc and manganese source in the diet for layinghens on eggshell and bones quality. Vet. Med., v.53, p.555-563, 2008.

TEIXEIRA, A.O.; LOPES, D.C.; RIBEIRO, M.C.T. et al. Composição química de diferentes fontes de fósforo e deposição de metais pesados em tecidos de suínos. Arq. Bras. Med. Vet. Zootec., v.57, p.502-509, 2005.

VIEIRA, S.L. Chelated minerals for poultry. Braz. J. Poul. Sci., v.10, p.73-79, 2008.

YENICE, E.; MIZRAK, C.; GÜLTEKIN, M. et al Effects of organic and inorganic forms of manganese, zinc, copper, and chromium on bioavailability of these minerals and calcium in late-phase layinghens. Biol. Trace Elem. Res., v.167, p.300-307, 2015. 